\title{
Effectiveness of Consortia Platform in Enhancing Paddy Farmers' Access to Market in Sengerema, Tanzania
}

\author{
Temitope Joseph Musowo ${ }^{1}$, Olushola Samuel Fadairo ${ }^{2}$, Muhoni Leonard ${ }^{3}$ \\ ${ }^{1}$ Department of Social Sustainability, Centre for Sustainable Development, University of Ibadan, Ibadan, Nigeria \\ ${ }^{2}$ Department of Agricultural Extension and Rural Development, University of Ibadan, Ibadan, Nigeria \\ ${ }^{3}$ Marketing Infrastructure, Value Addition and Rural Finance (MIVARF), Arusha, Tanzania
}

Email address:

topejseph@gmail.com (T. J. Musowo), dairom2@gmail.com (O. S. Fadairo), muhoni@gmail.com (M. Leonard)

\section{To cite this article:}

Temitope Joseph Musowo, Olushola Samuel Fadairo, Muhoni Leonard. Effectiveness of Consortia Platform in Enhancing Paddy Farmers' Access to Market in Sengerema, Tanzania. International Journal of Sustainable Development Research. Vol. 5, No. 2, 2019, pp. 41-55. doi: $10.11648 /$ j.ijsdr.20190502.12

Received: May 3, 2019; Accepted: June 18, 2019; Published: July 26, 2019

\begin{abstract}
Agriculture has a high potential to contribute to poverty reduction and economic development. The sector in United Republic of Tanzania is however dominated by smallholder farmers whose productivity and income remained stagnated due to many challenges, one of which is poor knowledge of market mechanisms and how to link with buyer groups to sell their produce/products. To address this challenge particularly among paddy (rice) farmers in Sengerema District in Nwanza Region, a market linkage approach known as consortia platform model is being employed. This study investigated the effectiveness of this approach (consortia platform) by identifying the benefits or supports derived by the smallholder paddy farmers and also ascertain the change in productivity leading to improvement in level of sales and profitability as a result of their involvement in the platform. The methodology employed is Experimental and Control variable, to investigate any change in productivity and income of smallholder farmers before and after their membership of the consortia platform. Mixed methods of both qualitative and quantitative were employed to gather data using structured questionnaire, Key Informant Interview (KII), Focused Group Discussion (FGD) while both primary and secondary data were equally gathered. The result clearly showed an improved market opportunities and increased value addition for the famers, which has ultimately resulted to increased incomes of the smallholder producer. These benefits primarily result to: (i) improved access to markets and information; reduced transaction costs, reduced post-harvest losses, enhanced food safety, improved product quality and increased producer (farm gate) price.
\end{abstract}

Keywords: Consortia Platform, Smallholder Producers, Paddy Farmers, Access to Market

\section{Introduction}

A good percentage of people in developing countries live in rural areas and depend on agriculture for their livelihoods. However, for agriculture to become a tool for economic development, a revolution in smallholder productivity is necessary. In East Africa, agriculture account for about $80 \%$ of the workforce, yet, East Africa Community (EAC) is characterised with low agricultural productivity and low income, thus, rated amongst the poorest in Africa, [1] According to State of East Africa Report (2016), about 11, 679, 275 people particularly in Tanzania still live below poverty line. These 37, 613, 489 representing $67.7 \%$ of people live in the rural areas and semi-rural, majority of them are smallholder farmers who depend on agriculture for their means of livelihood. [2, 3] reported that poverty in Tanzania is more endemic among households engaged in crop farming, livestock keeping, fishing and forestry. This is due to the fact that these smallholder farmers are constrained by low productivity and income paucity resulting from poor access to market, lack of access to credit facility and technology, poor access to farm input among other problems [4].

One of the major challenges militating against the efforts of the smallholder producers is access to market. Market access for farmers means the ability to acquire farm inputs and the capability to deliver agricultural produce to buyers. Access to domestic and international markets by smallholder producers means they can sell more produce at higher prices. With improved resources, farmers can link up with new 
markets and engage in value-adding activities. [5]

However, the smallholder farmers in the paddy value chain particularly still battles with the challenge of access to market. Paddy production is also being affected by the problem. Meanwhile, according to a baseline report byMarketing Infrastructure, Value Addition and Rural Finance (MIVARF, 2017) [6] Meanwhile, However, a consortium approach was introduced to bring together with equal representation the small producer farmer groups, the buyers/off takers, improved input providers, implement providers, finance providers, extension service providers, market information providers and other stakeholders, with government at the other end standing as a regulatory body. [7] These stakeholders come together to do business as they plan for the planting season with market specifications as a guide for their activities.

\subsection{Statement of the Research Problem}

Studies have been carried out on farmers' access to market, effective market linkage approach, innovation platforms and so on, [8-12] but no study has been specifically carried out to investigate the effectiveness of consortia platform as a market linkage approach among paddy farmers, particularly in Sengerema District. Farmers in Sengeremain particular were producing paddy/rice, but every season they struggle to access the needed farm inputs (improved seeds, quality fertilizers and crop protection products) at the right time, in the right quantity and quality and for a reasonable price. They often do not have the needed cash or credit to pay for the inputs. After harvest, the farmers struggle to sell paddy. Often, they have no choice but to sell their paddy at the local market (middle man) for a low price. They were not organized (institutional arrangement) and do not have the capacity (skills) either to negotiate for better prices, or to store their paddy until prices increase. Even the basic options needed to add value were beyond their reach (MIVARF, 2017). [5] This problem is increasingly impeding their productivity, household livelihood and poverty alleviation.

Therefore, they need support that aims to organize and coordinate their production processes and establishes new market linkages. This underscores the essence of the current consortium approach which is expected to lead to transformation for the smallholder farmers. [12] Hence, this study aimed to ascertain the effectiveness of this consortium approach with regards to paddy (rice) production particularly in Sengerema District, Mwanza Region in Lake Zone of Tanzania.

\subsection{Objective of the Study}

The overall objective is to investigate effectiveness of the paddy consortia platform in enhancing smallholder producer access to market. Specific objectives are as follow:

1. identify the personal and enterprise characteristics of the smallholder paddy farmers participating in the consortia platform,

2. identify the benefit or kinds of support (training, finance, extension services/technical support, inputs, market information etc) derived from involvement in the consortia platform by the participating smallholder paddy farmers,

3. ascertain the change in productivity leading to improvement in level of sales and profitability among smallholder paddy farmers as a result of their involvement in the consortium platform,

4. determine the challenges faced by smallholder paddy farmers in their involvement in the consortia, consortium platform.

5. examine the critical factors for sustainability in the structure/partnership model of the paddy consortium platform; and,

6. examine how smallholder farmers perceive and engage with other stakeholders on the consortia platform.

\subsection{Significance of the Study}

The study will bring to fore and ascertain effective market linkage approach that can enhance smallholder farmers' access to market which will lead to improved market opportunities and increased value addition for the famers. This will ultimately result to increased incomes of the smallholder producers. These benefits will primarily result to: (i) improved access to markets and information; (ii) reduced transaction costs; (iii) reduced post-harvest losses; (iv) enhanced food safety; (v) improved product quality and increased producer (farm gate) prices; (vi) increased output and productivity; and (vii) improved economies of scale. It will also increase output, income and employment in rural areas.

\section{Literature Review}

\subsection{Conceptual Framework}

People go into farming not just for the purpose of meeting their needs for food alone, but to earn a living through it. Agriculture in itself is a business through which farmers and other stakeholders in agribusiness look forward to making profit and raising their standard of living. Smallholder farmers who are major players in the agric value chain encounter many challenges while trying to increase their productivity and income level. [13] The issue of access to market is a major one.

The main issues in this study are; Smallholder Producers who are referred to in the study as those farmers who cultivate $21 / 2$ acres of land and bellow; The Consortium Platform, as a market linkage approach, how it is structured to enhance smallholder farmers' access to market. The consortium platform is used interchangeably with innovation platform at a point in the study. The study focuses on Paddy Farmers in Sengerema District in Mwanza Region of Tanzania.

\subsection{Emperical Review}

Literature however abounds on access to market as a major 
problem confronting agribusiness particularly among smallholder farmers. Many scholars have written on this subject of market access or access to market as the case may be. Although, this is seen from different perspectives by scholars in different fields like; Marketing Communications, Consumerism, Business Administration, Public Relations and Advertising, Commerce and Industry, International Trade and so on. However, in agribusiness, produce market is it. According to IFAD 2010, market access for farmers means the ability to acquire farm inputs and farm services, and the capability to deliver agricultural produce to buyers, similarly [5], Van Schalkwyk et al., (2012) [14] opined that markets provide the opportunity to generate income, contributing to a reduction in poverty and hunger in developing countries. Markets also drive production to meet consumer demand in terms of quantity and quality.

\subsection{Market Linkage Approach and Innovation Platforms}

According to Klerkx, L. et al, (2012), [15] Innovation platforms are ways to bring together different stakeholders to identify solutions to common problems or to achieve common goals. They ensure that different interests are taken into account, and various groups contribute to finding solutions. It is used by the private sector to gather information and improve networking among key stakeholders in a particular economic sector.

Lundy M. et al., (2012) [16] put it this way; "an innovation platform is a group of individuals (who often represent organizations) with different backgrounds and interests: farmers, agricultural input suppliers, traders, food processors, researchers, government officials etc". The members come together to develop a common vision and find ways to achieve their goals. They may design and implement activities as a group or coordinate activities by individual members. Individual members can also innovate alone, spurred by the coordinated group activities. Innovation platforms may tackle challenges and opportunities at various levels: in a village or community, in a district or nationwide, or throughout a value chain or economic sector [11]. They may work at a single level, or across several levels.

\subsection{Market Linkage Approach}

FAIDA 2000 sees Market Linkage as a good way of promoting and strengthening farmer groups. Farmer groups experience the simple principle of economies of scale when they jointly organize input distribution, extension and output collection. [17] This generally results in a strong basis to build business-oriented farmer groups. With this basis firmly established, the groups can be further strengthened in areas such as savings and credit, collection of marketing information, reviewing new business opportunities etc. Additionally, groups could work together for specific purposes such as lobbying policy makers, acquire donor funding, joint infrastructural investments, etc. However, all the above literature looked at market linkage generally but the focus of this work is paddy farmers.

\subsection{Producer Empowerment Market Linkage (PEML)}

\begin{tabular}{|c|c|c|c|}
\hline $\begin{array}{l}\text { Well Organized } \\
\text { Business Oriented } \\
\text { Experienced \& Dedicated } \\
\text { to Commercial Farming } \\
\text { Enterprises } \\
\text { But with profitability and } \\
\text { growth limited by poor } \\
\text { access to competitive } \\
\text { markets that reward } \\
\text { quality and/or reliable } \\
\text { supplies of quality input }\end{array}$ & \multicolumn{2}{|c|}{$\begin{array}{l}\text { Well Developed } \\
\text { Invested in: } \\
\checkmark \text { Processing Plant(s) } \\
\checkmark \text { Warehousing } \\
\checkmark \text { Transportation } \\
\checkmark \text { Effective linkage to } \\
\text { market } \\
\text { But with critical obstacles to } \\
\text { profitability and growth } \\
\text { caused by inadequate supply } \\
\text { of good quality raw materials } \\
\text { in the correct quantities and } \\
\text { at the right time }\end{array}$} & $\begin{array}{l}\text { Large and Significant in the } \\
\text { Quantities Demanded; } \\
\text { Support profitability for SHFs } \\
\text { and other in the VC, by } \\
\text { rewarding: } \\
\quad \checkmark \text { Quality and Food-safety } \\
\text { Standards; } \\
\checkmark \text { Economies of scale; } \\
\text { and } \\
\checkmark \text { Timeliness of delivery. }\end{array}$ \\
\hline $\begin{array}{l}\text { Farmers } \\
\text { Farming Business } \\
\text { Enterprises (FBEs) }\end{array}$ & & $\begin{array}{l}\text { d Firm } \\
\text { essor or } \\
\text { Trader }\end{array}$ & $\begin{array}{l}\text { End Market } \\
\text { National, Regional } \\
\text { or International }\end{array}$ \\
\hline $\begin{array}{l}\text { Commercial Suppliers c } \\
\text { Services such as: } \\
\square \text { Aggregation and local tra } \\
\square \text { Equipment and transpor } \\
\text { leasing) } \\
\square \text { Finance } \\
\square \text { Seed \& other Inputs } \\
\text { But with critical obstacle } \\
\text { profitability \& growth ca } \\
\text { irregular \& low volumes }\end{array}$ & $\begin{array}{l}\text { nputs \& } \\
\text { ire or } \\
\text { demand }\end{array}$ & $\begin{array}{l}\text { Providers o } \\
\text { as: } \\
\text { च Founda } \\
\square \text { Extensi } \\
\square \text { Quality } \\
\square \text { Capacit } \\
\text { WITH: } \\
\text { Mandate to }\end{array}$ & $\begin{array}{l}\text { ublic Good Services such } \\
\text { Seed } \\
\text { Services } \\
\text { I Standards } \\
\text { uilding } \\
\text { port VCD }\end{array}$ \\
\hline
\end{tabular}

Figure 1. The consortium model, MIVARF (2017) [5]. 
According to a project completion report compiled by James Wembe of Agri-business Development Company Limited, Tanzania, the Government of the United Republic of Tanzania in collaboration with the International Fund for Agriculture Development (IFAD) and the African Development Bank (AfDB), is implementing the Marketing Infrastructure, Value Addition and Rural Finance Support Programme (MIVARF), which is a seven year Programme (2011-2017), though, now extended for another two years.

The MIVARF Programme according to report is up-scaling the best practices and the lessons learnt are drawn from Agricultural Marketing Systems Development Programme (AMSDP) and Rural Finance Services Programme (RFSP). The Programme focuses on improving access to financial and marketing services for the rural economically active poor while emphasizing on financial and commercial viability and sustainability in the support of the beneficiaries. The overall goal of the Programme is to reduce rural poverty and accelerate economic growth on a sustainable basis in line with the framework of the national development strategies which include MKUKUTA/MKUZA, ASDP, ATI, KILIMO KWANZA and SAGCOT). In achieving MIVARF Goal, the program tasked Agribusiness Development Company limited to implement Producer Empowerment Market Linkage (PEML) component in Katunguru, Kishinda, Nyanzenda, Nyakasungwa and Nyakaliro wards of Sengerema district with focus on reducing rural poverty (income poverty and food poverty) (MIVARF, 2017) [5].

\section{Introduction Methodology}

The study on the effectiveness of paddy consortia platform in enhancing smallholder producers' access to market in Sengerema District, Mwanza Region in Lake Zone of Tanzania, was carried out between March and May, 2018. It involved field visits to smallholder farmers groups in the district. Interviews were held with key informants and stakeholders in the project. The study review and drew from works of many authors on consortium approach and access to market.

\subsection{Study Area}

Tanzania is a country in East Africa bordered by Kenya and Uganda to the North: Rwanda, Burundi, and Democratic Republic of Congo to the West: Zambia, Malawi and Mozambique to the South; and the Indian Ocean to the East. Tanzania economy depends heavily on Agriculture, which accounts for more than a quarter of GDP (Karfakis \& Rapsomanikis, 2018). [18] [14] Sengerema District is one of the 8 districts of Mwanza Region in Lake zone in Tanzania. The district is located south West of Mwanza City Council. The District is35 kilometres from Mwanza City and has an area of 8, 817 square kilometres. The 3, 335 square kilometres is dry while 5, 482 square kilometres is covered by water (Lake Victoria). According to the national census of 2012, [11] the district had a total population of 663,034 . The major occupations of the people are agriculture, livestock keeping and fishing. [15] However, the big share of district's income (about $80 \%$ ) is contributed by the agricultural sector which employs more than $90 \%$ of the total residents of the district.

\subsection{Population of the Study}

The population of the study comprise of all the 1,376 smallholder farmers involved in the paddy consortia platform in Sengerema District, Mwanza Region of Tanzania, 747 of them are men while 629 of them are women. There are 49 famers groups under this platform with average of 30 members in each group [5].

\subsection{Sampling Procedure}

The study sampling procedure employed was a multistage approach sampling method. Purposive sampling method was used to choose all paddy consortia platform in Sengerema District out of the 8 districts in Mwanza Region. Purposive selection of 4 out of 5 wards in Sengerema District, then, random selection of 12 out of 14 villages that are potential in paddy production of 21 villages in the five wards.

\subsection{Sample Size Determination}

Random selection of 30 out of the 49 farmers groups affiliated to the consortium platform in Sengerema District. Averages of 11 respondents were randomly selected to represent each of the 30 groups. Simple Random Sampling technique was used to select 344 smallholder paddy farmers out of 1,376 farmers involved in the consortium platform. Convenience sampling was also used to select 16 other stakeholders in the value chain, who includes; heads of farmers groups, executive members of AMCOS, head of innovation platforms, service providers, head of a consortium platform, extension service officers, Branch Manager of Micro Finance Bank.

To ensure the validity and reliability of the instruments, a pre test was done in another area other than the study area to assess the ability of the respondents to interpret and administer the questionnaire. While the instruments were also submitted to both local and on-sight supervisor for necessary correction.

\subsection{Data Collection Procedure and Instrument}

Both quantitative and qualitative data were gathered, using primary and secondary data sources. Factual information on effectiveness of Paddy Consortia platform in enhancing smallholder farmers access to market was gathered through the use of structured questionnaire, (close and open-ended). Data gathered through direct observation on the field.

The secondary data were collected from journals, newsletters, baseline survey, published research works and books. Key Informant Interview (KII), Focused Group Discussion (FGD) was also used to gather qualitative data from the operator of the consortia platform and other stakeholders. In all, 4 wards (Katungwa, Nyakasungwa, Kishinda and Nyakaliro) and 12 villages (Kutunyuru, 
Kasomeko, Nyankasungwa, Majengo, Igwanzozu, Kishinda, Tunyenye, Mami, Isebya, Kasela, Itumbili, Nyakaliro) were reached through motorcycle.

\subsection{Measurement of Variables}

There are three major variables to measure the effectiveness of the paddy consortia platform in sengerema district are;

1. The level of sales (change in unit sales) by the farmers before and after their involvement in the platform

2. The profitability (unit margin) of the farmers before and after their involvement in the platform

3. Benefits/support derived by the farmers before and after their involvement in the platform

\subsection{Methodology: Experimental and Randomized Control Variable}

The study employed randomization in order to demonstrate a causal relationship between intervention of consortium approach and outcomes on production and income of smallholder farmers before and after involvement in the paddy consortium platform in Sengerema district. Randomized control trials estimate program effectiveness by comparing participant outcomes before and after the intervention of consortium approach.

\subsection{Method of Data Analysis and Techniques}

The already coded data were analyzed using Statistical Package for Social Sciences (SPSS statistics IBM 20) and MS Excel spreadsheet. Both qualitative and quantitative data were generated for the study and presented through combination of cross tabulation, graphs, and chats. Descriptive statistics were used (frequencies, percentage, ratio, means, and standard deviation). Inferential statistics ( $t-$ test) were equally used to ascertain the distribution of variables in the study to determine the general effectiveness of the consortium approach in the study areas. Data on Objective 2, 3 and 4 was generated using questionnaire, KII, FGD guides and analyzed using descriptive statistics (percentage, frequencies, mean and standard deviation) and inferential statistics (t-test and p-value).

Derivative of Objective 5 and 6 were drawn from questionnaire, KII, FGD guides, observation and documentation review and analyzed.

\section{Data Presentation and Interpretation}

\subsection{The Respondents' Demographic Information and the Economic/Enterprise Demographic Information}

The demographic information of the respondents was first presented before going on to the main analysis. Thus, based on the returned questionnaires coded and entered into SPSS, presented in Table 1 below are the respondents' personal characteristics.

The spread in Table 1 below depicts the categories of smallholders farmers involved in the survey and the essence is to ensure that the most appropriate respondents were selected for the study.

Table 1. Demographic Data of the Respondents.

\begin{tabular}{|c|c|c|c|c|c|c|c|}
\hline \multirow{2}{*}{$\begin{array}{l}\text { Gender (\%) } \\
\text { Male }\end{array}$} & \multicolumn{3}{|c|}{ Age (\%) } & \multicolumn{2}{|l|}{ Education Q.(\%) } & \multicolumn{2}{|c|}{ Marital Status (\%) } \\
\hline & $191(55.5)$ & $18-30$ & $18(5.2)$ & No Formal Education & $10(2.9)$ & Single & $16(4.7)$ \\
\hline Female & $153(44.5)$ & $31-40$ & $50(14.5)$ & Quranic Education & $8(2.3)$ & Co-habiting & $13(3.8)$ \\
\hline & & $41-50$ & $159(46.2)$ & Primary Education & $281(81.7)$ & Married & $263(76.5)$ \\
\hline & & $51-60$ & $88(25.6)$ & Junior Secondary Education & $41(11.9)$ & Separated & $22(6.4)$ \\
\hline & & Above 61 & $29(8.4)$ & Senior Secondary Education & $2(0.6)$ & Divorced & $6(1.7)$ \\
\hline & & & & Tertiary Education & $2(0.6)$ & Widowed & $24(7.0)$ \\
\hline
\end{tabular}

Source: Field Survey 2018

\subsection{Economic/Enterprise Demographic Information}

Having evaluated the education levels of the respondent as well as their marital status and gender, it isappropriate to determine the economic/enterprise characteristics of the respondents to know the extent to which they are faring since their involvement in the paddy consortium platform.

Table 2. Economic/Enterprise Data of the Respondents.

\begin{tabular}{|c|c|c|c|c|c|c|c|c|c|}
\hline \multicolumn{2}{|c|}{ Family Size (\%) } & \multicolumn{2}{|c|}{ Monthly Income (\%) } & \multicolumn{2}{|c|}{ Size of Farmland } & \multicolumn{2}{|l|}{ Source of Labour } & \multicolumn{2}{|c|}{ Source of Farmland (\%) } \\
\hline 1-5 People & $61(17.7)$ & $<20$ USD & $29(8.4)$ & $<1$ Acre & $39(11.3)$ & Family members & $202(58.7)$ & Self-owned & $198(57.6)$ \\
\hline 6-8 People & $116(33.7)$ & 21 USD-40 USD & $285(82.8)$ & 1-2 Acres & $161(46.8)$ & Communal effort & $13(3.8)$ & Inherited & $112(32.6)$ \\
\hline 9-10 People & $99(28.8)$ & 41 USD-60 USD & $21(6.1)$ & 2-3 Acres & $75(21.8)$ & Hired & $128(37.2)$ & Borrowed & $27(7.8)$ \\
\hline \multirow[t]{2}{*}{ Above 11} & $68(19.8)$ & 61 USD-80 USD & $9(2.6)$ & 3-4 Acres & $51(14.8)$ & Others & $1(0.3)$ & Lease & $4(1.2)$ \\
\hline & & & & 4-5 Acres & $18(5.2)$ & & & Joint ownership & $3(0.9)$ \\
\hline
\end{tabular}

Source: Field Survey 2018

\subsection{Cross Tabulation Between Personal and Enterprise Characteristics of the Smallholder Paddy Farmers}

This is to find out the hidden facts and if there is any cross relationship between these characteristics. 
Figure 2 reveals a correlation between family size and the production as majority of respondents who cultivate above 5 acres have between 9- 10 people living in their household.

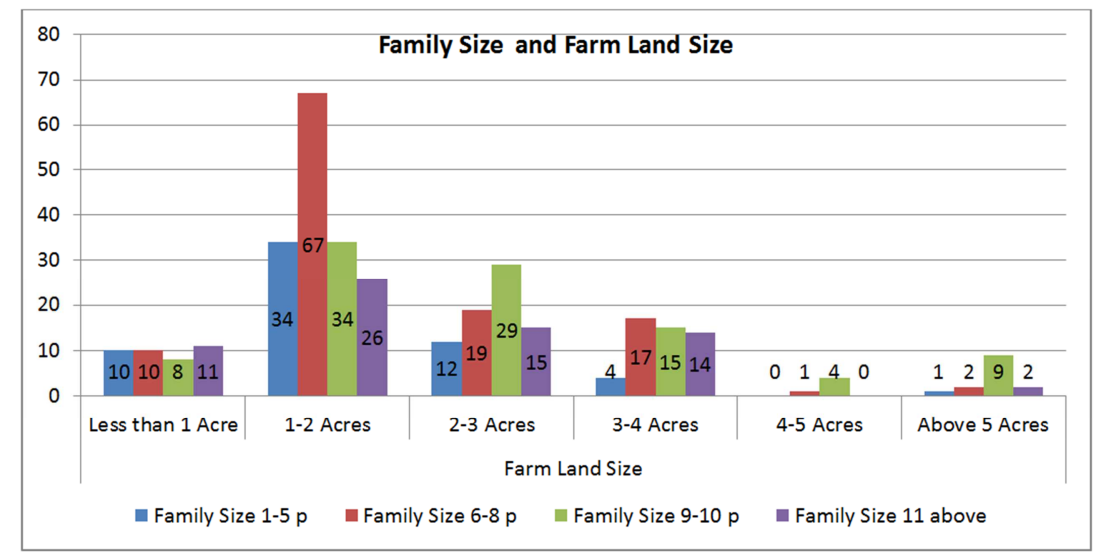

Source: Field Survey 2018

Figure 2. Showing crosstab between family size and farmland size.

Figure 3 reveals that male respondents obviously cultivate more than the female respondents.

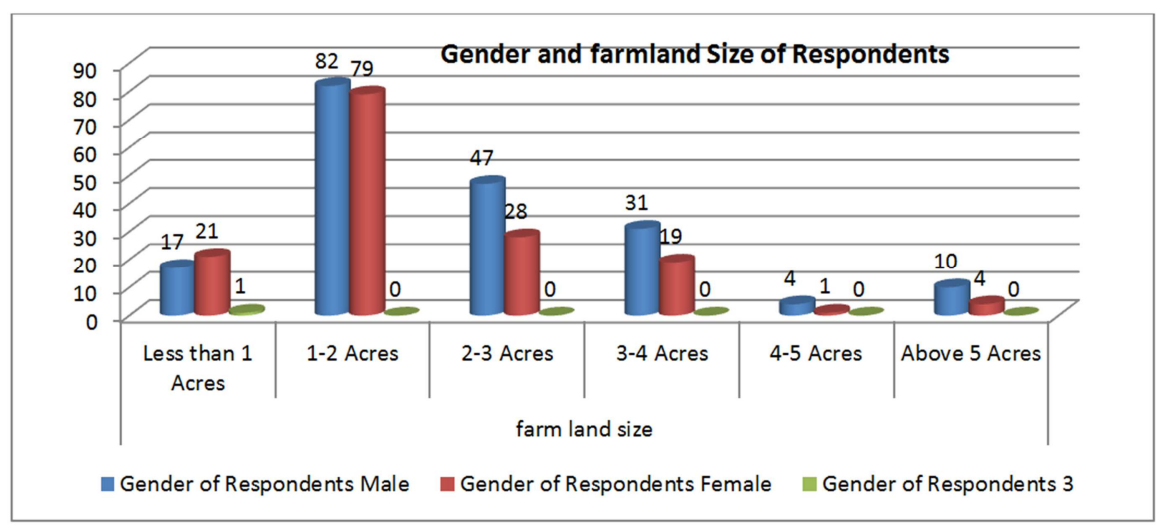

Source: Field Survey 2018

Figure 3. Showing crosstab between gender and farmland size.

Figure 4 shows that respondents who cultivate more number of acres used hired labour, while people who use only family labour cultivate less.

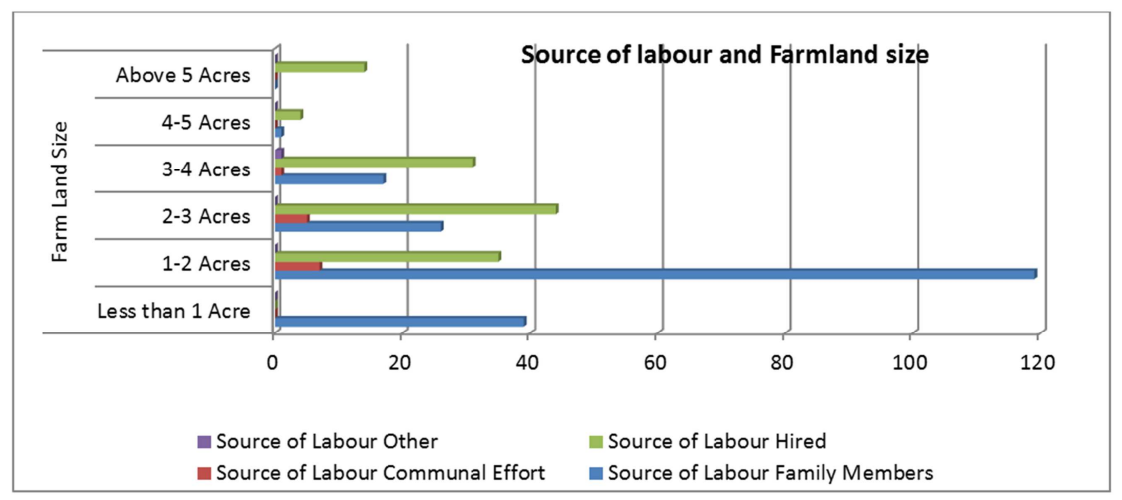

Source: Field Survey 2018

Figure 4. Showing crosstab between source of labour and farmland size.

Figure 5 reveals that level of education has nothing to do with production, majority of the people who cultivate 4 acres and above don't even have more than primary school education. 


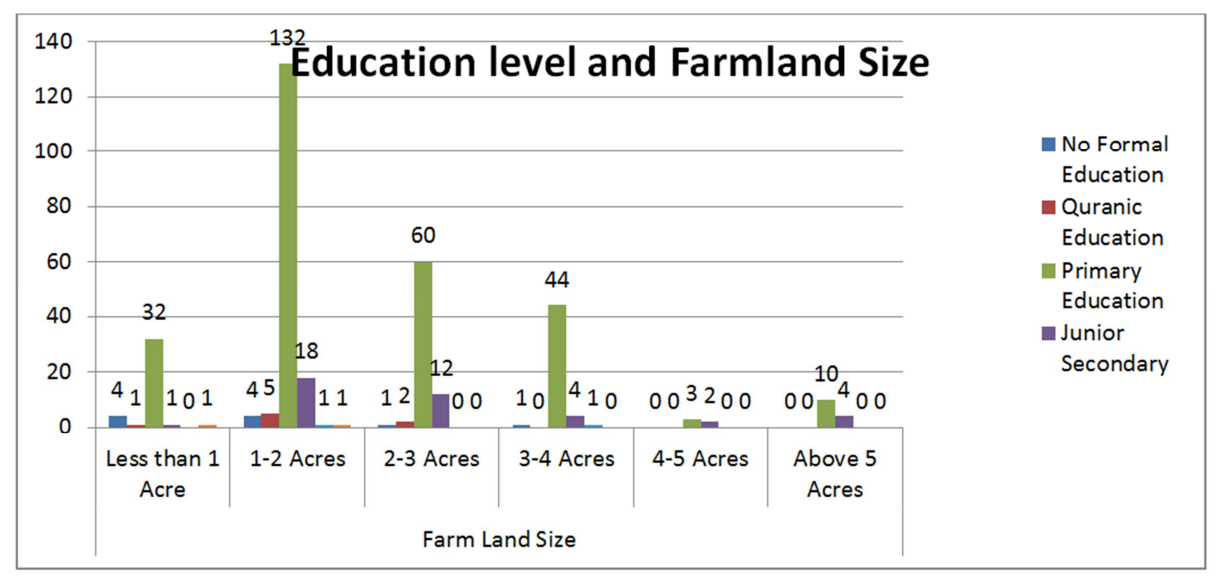

Source: Field Survey 2018

Figure 5. Showing crosstab between education qualification and farmland size.

Figure 6 indicate that majority of the respondents $(46.8 \%)$ do not cultivate more than 2 acres which implies that the respondents are indeed smallholders farmers.

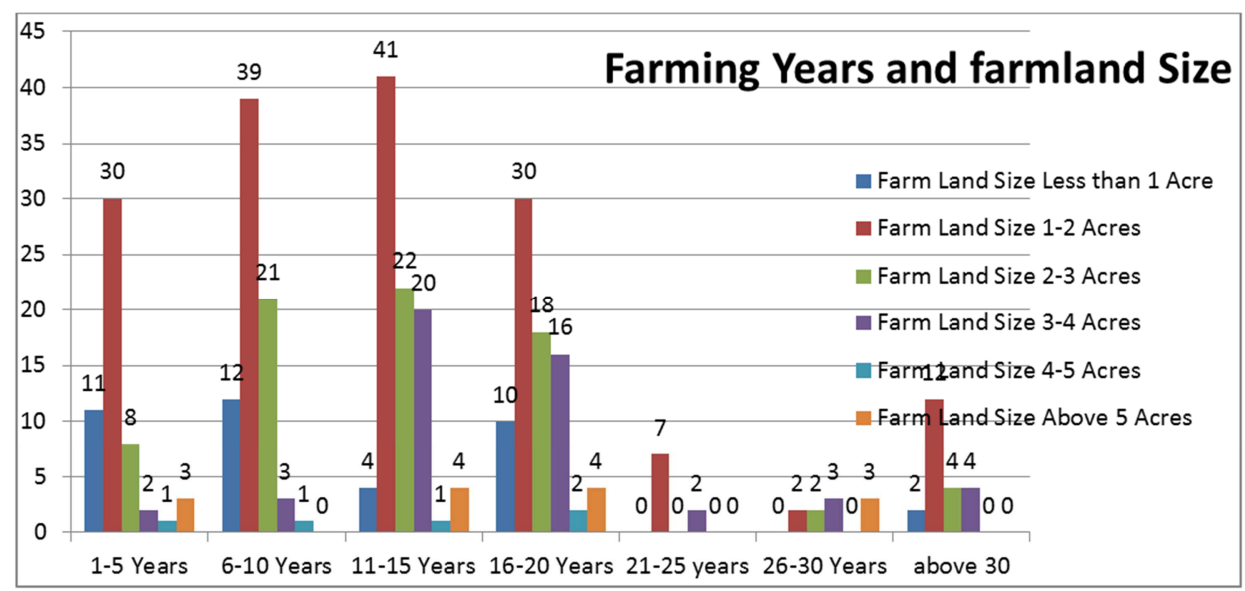

Source: Field Survey 2018

Figure 6. Showing crosstab between years of farming and farmland size.

The result in Figure 7 negates the assumption that those who do not combine other business with paddy farming would have more time and concentration to cultivate more, as respondents with other source(s) of income cultivate more than those without other source of income.

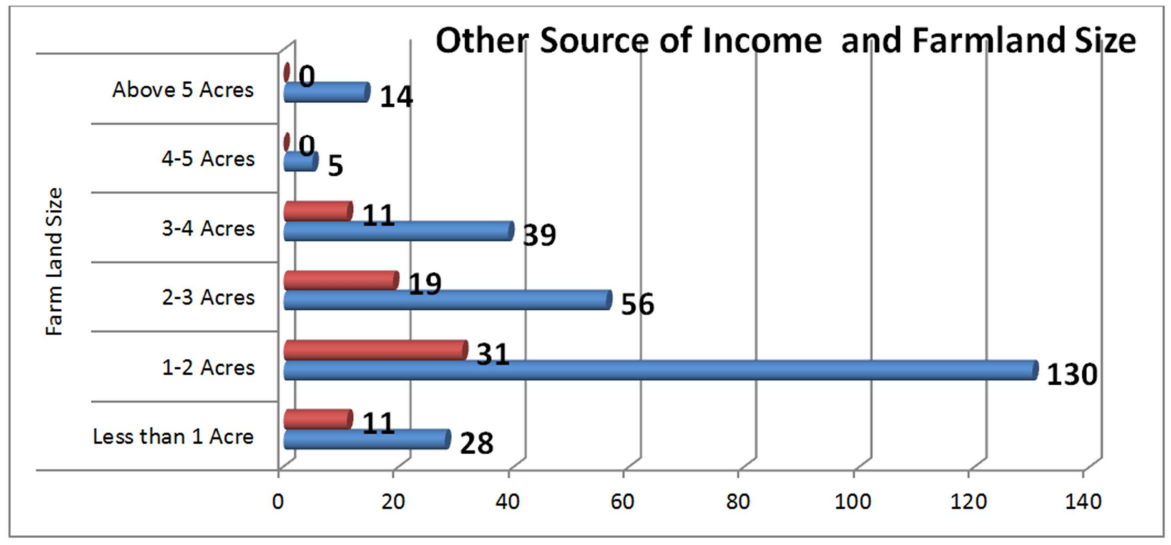

Source: Field Survey 2018

Figure 7. Showing crosstab between other source of income and farmland size. 


\subsection{Benefits Derived from the Consortia Platform by Paddy Farmers}

The study revealed that majority of the smallholder producer farmers lack support which can help them in farm activities and enhance their access to market before joining the paddy consortium platform. Smallholder producers have little or no access to benefits such as; financial assistance, input supply, market information, training, extension services among others.

The result reveals that $41.6 \%$ and $58.6 \%$ of the respondents had it somewhat difficult or no access to financial assistance. However, $27.6 \%$ and $54.1 \%$ of them admitted that their association with the paddy consortium platform affords them very easy and easy financial assistance, with very few among them still finding it somewhat difficult or having no access at all (collectively, 18.3\%). Similarly, $66.0 \%$ and $34.0 \%$ of the respondents find it somewhat difficult or no access to input supply, and $51.2 \%$ and $48.3 \%$ of them admitted that their induction to the consortium platform afford them very easy and easy access to input supply. $44.2 \%$ and $55.8 \%$ of the respondents have somewhat difficult or no access to market information while $47.7 \%$ and $51.1 \%$ of them admitted that their induction to the consortia platform affords them very easy and easy access to market information. $23.5 \%$ and $53.8 \%$ of the respondents acknowledged that they have access to training before their admission to the consortium platform, while very few of them admitted it was somewhat difficult or no access to training before their admission to the platform.

However, the paddy consortium platform has improved the level of their access to training for about $22.1 \%$, with majority of them now having access to exclusive training (collectively, 99.4\%).

The results further showed their access to extension services, $20.9 \%$ and $72.1 \%$ of the respondents have very easy and easy access to extension services, with very few of them finding it somewhat difficult having access to it before their admission to the consortium platform. Meanwhile, the platform improved their access to extension services just for about $6.7 \%$. Conclusively, $66.0 \%$ and $43.3 \%$ of the respondents had it somewhat difficult and no access to other things which were not capture in the survey, while $43.0 \%$ and $55.5 \%$ of them admitted that their involvement in the consortium platform afford them very easy and easy access to these other things. This implies that the government of Tanzania is working hard in providing training and extension services for their farmers, which is a laudable idea.

\subsection{Supports for Paddy Farmers Through the Platform}

The findings reveal the level of satisfaction derived by paddy farmers as a result of the support from the consortium platform. However, $40.7 \%, 58.4 \%$ and $0.9 \%$ of the respondents acknowledged that the timeliness in getting supports from the consortium platform as very satisfactory, satisfactory and fair. $58.4 \%, 41.3 \%$ and $0.3 \%$ of the respondents acknowledged the frequency of supports derived from being a member of the consortium platform as very satisfactory, satisfactory and fair. Moreover, 47.7\%, 52\% and $0.3 \%$ of the respondents acknowledged the cost effectiveness of the supports derived from being a member of the consortia platform as very satisfactory, satisfactory and fair.

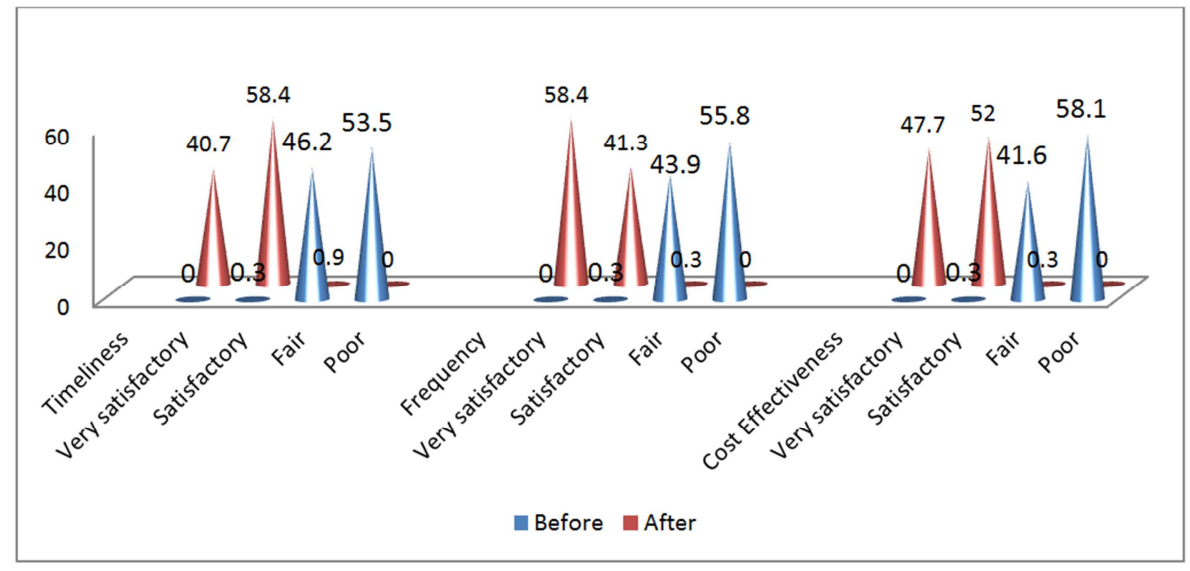

Source: Field Survey 2018

Figure 8. Level of satisfaction of members Paddy Consortia Platform.

\subsection{Change in Productivity and Improvement in the Level of Sales and Profitability}

Figure 9 below shows the change in productivity that all of the smallholder producers have witnessed since their involvement in the consortium platform, figure 10 reveals the membership of farmers association of the paddy farmers, while figure 11 shows their level of access to market before and after they become a member of the consortium platform. It is worthy of note that all of them have witnessed tremendous change in the level of productivity $(100.0 \%)$, $94.4 \%$ of the respondents were member of association before their involvement in the consortium platform, all of them became a member of association through the paddy consortia platform. In this context, it was revealed that the benefits which are accessible to members of the consortium platform 
drew the interested of the smallholder producers to becoming members of farmers association. However, figure 11 reveals that all these smallholder producers initially had poor access to market $(100.0 \%)$. Meanwhile, their involvement in the consortium platform has provided them full access to market to sell their farm produce, with all of them now having $100.0 \%$ access to market.

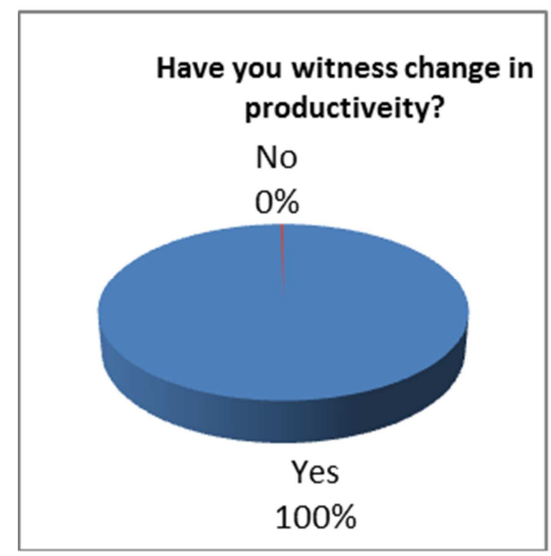

Source: Field Survey 2018

Figure 9. Showing change in productivity.

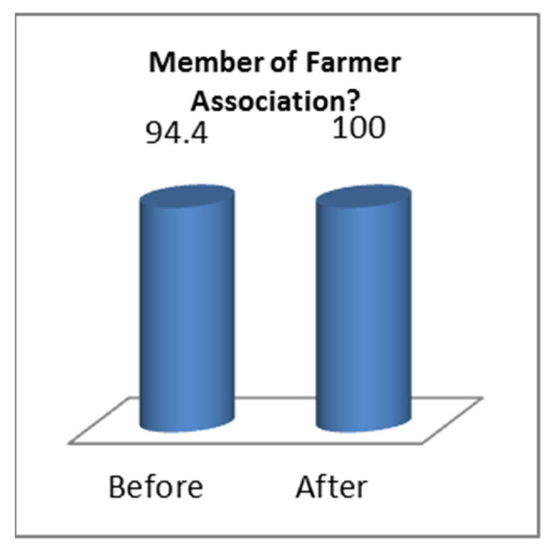

Source: Field Survey 2018

Figure 10. Showing membership of farmer ass.

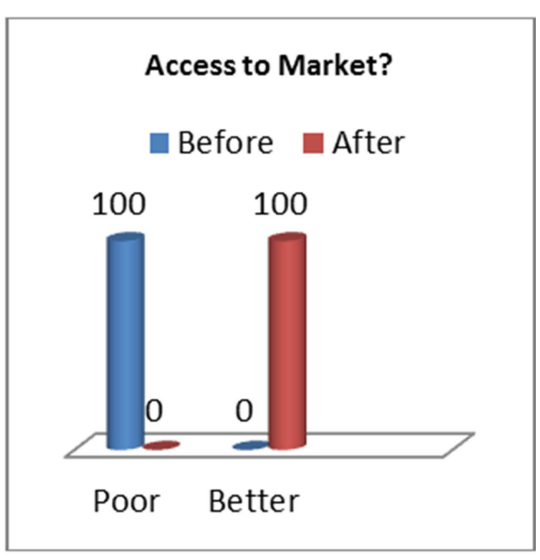

Source: Field Survey 2018

Figure 11. Showing access to market.

\subsection{Change in Productivity of Paddy Farmer Since Involvement in the Platform}

The outcome showed that some of the changes witnessed by smallholder producers and their experiences in term of productivity before and after their involvement in paddy consortia platform, the changes they witnessed ranges from size of farmland, yield per acre, source of labour, and average income per season to farm ownership. The result reveals a drastic increase in the size of farmland cultivated by these smallholder producers after their involvement in the paddy consortium platform. The respondents that cultivated between $2-5$ acres and above 5 acres of farmland were about $38.4 \%$ and $3 \%$ respectively, their involvement in the consortium platform have increased the size of farmland they cultivated to about $62.6 \%$ and $7 \%$ respectively. The respondents that experienced changes in yield per acres between $1000-6000 \mathrm{~kg}$ and $6000 \mathrm{~kg} \&$ above were about $49.2 \%$ and $3 \%$, their involvement in the platform have increased the level of yield per acres to about $73.2 \%$ and $6.7 \%$ respectively.

However, In addition, the spread also reveals the source of labour of these smallholder producers, $68.9 \%, 15.4 \%$ and $15.4 \%$ of them acknowledged their source of labour to be family members, hired labour, family \& hired labour. Meanwhile, their involvement in the platform have relieved their families from labour $(61.3 \%)$ and at the same time afforded them the opportunity to employ more hands into the farm (18\%), though combined labour of family\& hired increased to $20.3 \%$. The average incomeper season of the respondents experience changes as well, $61.9 \%$ and $3.3 \%$ of the respondents recorded between 500, 000Tsh to 4, 000, 000Tsh and 4,000,000Tsh to about 10,000,000Tsh income, their involvement in the platform have improve the level of their income per season. $77.4 \%$ and $13.8 \%$ of them recorded between $500,000 \mathrm{Tsh}$ to $4,000,000 \mathrm{Tsh}$ and $4,000,000$ tsh to above 10, 000, 000Tsh income. Furthermore, the respondents also experience better changes in farm ownership; $86 \%$, of them acknowledged that they inherited their farm, $13.7 \%$ self-owned and $0.3 \%$ hired their farm. Involvement in paddy consortia platform brought a change as $90.4 \%$ of them now haired their farm land, but there is a decrease in the percentage of self-owned to $9 \%$, while $0.3 \%$ of them leased and borrowed their farm respectively.

\subsection{Improvement in the Level of Sales and Profitability}

The study revealed the sales and profitability improvement that the smallholder producers have witnessed before and since their involvement in the consortium platform, the result further reveals an improvement in sales and profit, as well as other areas of improvement such as net profit, customer satisfaction, income in kind, market demand, economics of scale and other things which were not captured in the survey. All of them have witnessed tremendous change in the level of sales and profits (99.7.0\%). However, 0.3\%, 66.9\% and $32.8 \%$ of the respondents acknowledged that their net profit has improved, poorly improved and not improved 
respectively. Involvement in the consortium platform brought change to this, $31.1 \%, 67.7 \%$ and $1.2 \%$ acknowledged greatly improved, improved and poorly improved respectively. $0.3 \%, 0.3 \%, 52.3 \%$ and $47.1 \%$ of the respondents acknowledged their customer satisfaction has greatly improved, improved, poorly improved and not improved; while their involvement in the consortium platform also brought change to it, $45.3 \%, 54.4 \%$ and $0.3 \%$ acknowledged greatly improved, improved and poorly improved.

Moreover, $0.3 \%, 50.3 \%$ and $49.4 \%$ of the respondents acknowledged that their income in kind has improved, poorly improved and not improved; while their involvement in the consortium platform brought change to this, $46.2 \%, 53.5 \%$ and $0.3 \%$ acknowledged greatly improved, improved and poorly improved. $0.3 \%, 49.7 \%$ and $50 \%$ of the respondents acknowledged that their market demand has improved, poorly improved and not improved; while their involvement in the consortium platform brought changes to this, $45.6 \%$, and $54.4 \%$ of them acknowledged greatly improved, and improved. $0.3 \%, 50 \%$ and $49.7 \%$ of the respondents acknowledged that their economic of scale has improved, poorly improved and not improved; while their involvement in the consortium platform brought change to this, $48.8 \%$, $50.6 \%$ and $0.6 \%$ of them acknowledged greatly improved, improved and poorly improved. Lastly, 0.3\%, 49.7\% and 50\% of the respondents acknowledged improvement in other things pertaining to sales and profitability which were not captured in the survey as improved, poorly improved and not improved. Their involvement in the consortium platform brought about the changes recorded, $40.4 \%$, and $59.6 \%$ acknowledged greatly improved, and improved.

\subsection{Challenges Faced by Paddy Farmer in Their Involvement in the Consortium Platform}

This section discussed some of the challenges experienced by paddy farmers before and after their involvement in the consortium platform. The response shows the entire smallholder producers faced one challenge or the other $(100 \%)$. These challenges are; finance, access to produce market, access to input market, technical support, and storage facility amongst others. However, $49.7 \%$ and $50.3 \%$ of the respondents acknowledged severe and mild challenges in their finance; while their involvement in the consortium platform brought change to this, $0.6 \%, 0.3 \%, 62.5 \%$, and $36.6 \%$ acknowledged severe, mild challenge, not severe and not a challenge. $68 \%$ and $32 \%$ of the respondents acknowledged severe and mild challenges in their access to produce market; while their involvement in the consortium platform brought changes to this, $0.3 \%, 43.9 \%$, and $58.8 \%$ acknowledged mild challenge, not severe and not a challenge.

Moreover, $59 \%, 40.7 \%$ and $0.3 \%$ of the respondents acknowledged severe, mild challenges and not severe in their access to input market; while their involvement in the consortium platform brought changes to this, $0.3 \%, 0.9 \%$, $45.9 \%$ and $52.9 \%$ acknowledged severe, mild challenge, not severe and not a challenge. $29.9 \%, 45.9 \% .17 .4 \%$ and $6.7 \%$ of the respondents acknowledged severe and mild challenges, not severe and not a challenge in their technical support; while their involvement in the consortium platform brought changes to this. $2.0 \%, 44.9 \%$, and $53.2 \%$ acknowledged mild, not severe and not a challenge. 53.2\%, 45.3\% and 1.5\% of the respondents acknowledged severe and mild challenges and not severe in their storage facility; while their involvement in the consortium platform brought changes to this. $14.5 \%, 50.3 \%, 23 \%$ and $12.2 \%$ acknowledged severe, mild challenge, not severe and not a challenge. Lastly, 43\%, $55.8 \%, 0.9 \%$ and $0.3 \%$ of the respondents acknowledged severe and mild challenges, not severe and not a challenge in other challenging issues which were not captured in the survey; while their involvement in the consortium platform brought change to this, $54.4 \%$ and $46.6 \%$ acknowledged not severe and not a challenge.

\subsection{How Smallholder Farmers Perceive and Engage with Other Stakeholders on the Consortia Platform}

Qualitative data were gathered to respond to this particular objective through Key Informant Interview (KII) and Focus Group Discussion (FGD) with the head of smallholder farmers groups (chairman and secretary) head of Agricultural Marketing Cooperative Society (AMCOS) from each of the three desks (Marketing, Input, and Finance), head of the Service Providers among others. The following were the findings;

The programme started in 2015 with the service providers from Agri-business development companies mobilizing the farmers into groups. A constitution was prepared to guild the activities of members from regional levels down to the district level. All stakeholders on the platform are of equal importance and derive equal benefits. To access benefit on the platform you must be a farmer in Sengerema district and a member who is paying his membership dues regularly, attending meetings and obeying the rules and regulations of the platform. There is always pre planting season meeting and planning among members. This makes the farmers more knowledgeable in the area of better agricultural practice and soil management.

There is a principle of collective marketing which operate among the farmers, so, no farmer is expected to sell his produce alone or without bringing them to the warehouse. This practice ensure collective marketing and access to market, it gives them knowledge of trustees. Farmers on the platform have access to market information from the extension officers. There is warehouse receipt system whereby there is a management in charge of the warehouse with adequate security in place. The local market according to these people is unpredictable and unregulated so their produce are gathered together through the warehouse receipt system for onward transmission to the international market. The practice has improved micro businesses and market expansion.

Paddy value chain has components which link other products that give rise to other business activities. The system gives more advantage in terms of mechanism of linkage and capacity building of the smallholder farmers groups. It has improved youth involvement in other areas such as post 
harvest activities like transport business and food supply. The farmers enjoys government support in terms of good policies, regulations and infrastructure, with her development partners like Africa Development Bank, IFAD, MIVARF, Research Institutes and so on. Expectations of the members are met up to $80 \%$ according to the farmers. It was observed during the visit to the farm that the people have their farmland together even though there are demarcations; this will foster unity, brotherliness, team spirit and communal living.

\subsection{Critical Factors for Sustainability in the Structure/Partnership Model of the Paddy Consortia Platform}

Results were hinged on data gathered through KII, FGD with Service Providers, head of Financial Institutions, head of operation of the consortium platform, Agri-Business and Marketing Expert, etc, many of who were intercepted engaged during a stakeholders workshop which took place at Nyakahoja Conference Centre in Mwanza during the study.

According to Mr Muhoni Leonard, an Agri-business and Marketing Expert with MIVARF, the essence of the stakeholders workshop was to ensure that all parties involved in the agricultural value chain across the country are well linked together, established for a sustainable mutual operation even long after the foreign partners are out of the programme, he said, "It is a stakeholders workshop which is more or less like an orientation workshop, following the extension of the programme for two years which ordinarily ended in December last year (2017), so we gather all stakeholders together to chat the way forward in terms of orientation on how to implement the programme towards the en".

These stakeholders include officials from the Local Government Authorities, Implementing Agencies, Service Providers, private companies who are taking the capacity building to the smallholder producers, Also at the conference, were officials from the regional offices, those who are dealing with the cooperative issues, representatives from the financial institutions who are also partners in the programme, were all represented there.

Speaking about the approach being used to achieve result, Muhoni said, "Today we are looking at the consortium approach. This consortium approach is more of a trading platform where we have buyers or potential buyers who are not sure of where to get the produce, let's take paddy as an example, we have buyers and processors dealing in a large scale who find it is difficult to get their raw materials, in the other hand, we have the smallholder producers who have difficulties understanding what the market is, so, the programme is an idea of having a platform where partners in this value chain come together, the sellers of farm inputs, financial service providers and the off takers, all meet together to trade, whatever weakness any of the groups have within their enclave, take for instance, the smallholder farmer groups who are organised under Agricultural Marketing Cooperative Society, AMCOS or SACOS come up with their needs with the buyers at the platform level".

He also added that they usually have such workshop quarterly, where they meet with various stakeholders to have a review of their activities, how well they are achieving their set objectives to ensure a sustainability plan.

Another service provider, from the Sengerema District, facilitating linking farmers to the market through consortium model, Mr. James Wembe, also explained the consortium approach as a platform through which the Lead Firms, (the big Buyers) plan with the farmers in advance, the amount required based on market specification in terms of quantity, quality and frequency as well as mode of delivery.

"They plan together base on the market need, then farmers start producing to meet the market requirements unlike in the traditional way where farmers produce without market specification, but base on this consortium model.

The plan start with the market, both farmers and buyer dialogue through what we call pre season meeting and find the market need, by this we mean the produce market, the farm produce market which will enable the farmers know the farm input require, maybe, fertilizer, improved seeds. The quantity and variety as demanded by the buyer in advance base on market specification, then the financial requirements and how to link them to the financial market. So, this things are interconnected, they work in a collaborative way and through the consortium model which is a business collaborative meeting, all stakeholders come together to take advantage of the business opportunity", Wembe explained.

He stated further that before the introduction of the approach, traditionally, people were struggling to improve productivity but through the consortium approach challenges faced by farmers on market including storage, transport and so on are taken care of. "Market requirement determines the production pattern, how much the buyer will need from the financial institutions and the financial institutions become a part of the model because this is business for everyone, so this is different from the traditional way where farmers were at the centre but here market is at the centre of everything".

The model according to $\mathrm{Mr}$ James reduces cost for all stakeholders, the farmers, the buyers, input suppliers, financial institutions and so on. Instead of going around meeting individual which incurs more cost in terms of overhead, this is reduced because the consortium model brings everybody together.

As a sustainability plan, he explained that the periodic meeting afford them the opportunity of profiling all potential stakeholders, the off takers, AMCOS, input providers in their areas, who and who are into what?, what are the challenge?, how can they work together?, what assistance is needed from them?, do they need capacity building?, what role will the government play? and so on.

Still on sustainability, according to Wembe, there was contractual agreement between producers and buyers as they usually sign memorandum of understanding, so also between farmers and financial institutions, between farmers and input suppliers as well, AMCOS stands in for the farmers as a body under which farmer producer groups come together. Another form of checks is the collective marketing, nobody sells outside of the consortium arrangement, when their produce 
comes in after harvesting, AMCOS ensure that the loan obtained from the financial institutions is refunded, all the payments pass through the account and deductions are made directly before the farmers get their balance. In case of defaults, the measure put in place for recovery is insurance, not just for defaults alone but if anything goes wrong in a particular planting season. They also have the government as a regulatory body. Farmers who sell their farm produce without taking them to the warehouse face serious sanctions.

Mr Samuel Muganga, head of a Lead Firm, (AMIS MAZAO Group) based in Shiyanga, also said, there are supermarket and yearly exhibitions in every zone where offtakers come to buy at and zonal agricultural extension show. The government serves as a regulatory body for the activities of all the members on the platform. The Tanzania Bureau of Standard TBS as a national institution helps regulate the quality of produce to meet up with international market standard. When there was low production last year (2017), to prevent food scarcity in the country, the government came up with specification on the volume that should be sold out to foreign market. He said they are having a good deal and he could boldly say it is a mutually beneficial platform for all the members.

It is obvious from the data gathered that there is a sustainability plan on ground to ensure continuity of the programme.

\section{Summary, Conclusion and Recommendations}

\subsection{Summary}

From the result above, the demographic characteristics of smallholder paddy farmers in the paddy consortium platform in Sengerema shows that more men are into paddy farming than women and less youth are involved in paddy farming. It is also obvious from the result that a large majority of the farmers do not cultivate more than 2 acres of land.

The result also indicate that the size of the farmer's family has something to do with the size of land cultivated by the farmers, education level has nothing to do with production because majority of the farmers did not have more than primary school education including those who cultivate more than 4 acres of land.

The data show that majority of the farmer do not have problem in terms of training and extension services even before their involvement in the consortium platform, which help them with good agricultural practice. However, almost all of the farmers do not have the necessary support that could help their productivities like access to finance, input supply, market information which hinders production, this tremendously changed with the consortium platform.

The consortium approach awaken the consciousness of the smallholder farmers to farming as a business and not just a means of meeting family basic needs alone, this however do not mean that many of them have crossed from subsistent farming to commercial. Access to inputs enabled by inclusion of input suppliers in the consortium reinforced by input credit and loan from bank have direct impact on production outputs. The collective marketing system through warehouse receipt system also promotes access to market, supports improvement in production outputs. Collective action as a result of farmers group stimulates coordination and joint decision making. The availability of assured market drives upward trajectory of production output and volume off take by buyers. The level of increase in production and income recorded in the consortium indicated strong significance change over what was recorded before the consortium driven by increase in farmland cultivated.

\subsection{Conclusion}

Largely, the approach has been effective in enhancing the smallholder producers' access to market which is leading to increase in the level of sales and income. However, other potential stakeholders need to be identified and incorporated in the consortium team. The other potential stakeholders include: AMCOS/Value Chain, Agribusiness Company, Insurance company, Research centres, Value Chain Development Partner and Neutral facilitator.

The lessons learnt should be applied to strengthen and scale up the consortium approach to value chain development of SMEs in Tanzania and in the EAC and Africa.

Commitment of members and result recorded shows strong evidence of sustainability and that would be better appreciated long after development partner exit the programme and a post monitoring and evaluation should be conducted to ascertain the sustainability of post impacts of the consortium. The intervention of the consortium in the area of training, access to inputs, credit, delivery mechanism, payment modality and market linkage founded on collaborative value chain that yield to win-win partnership is relevant as a consortium approach development.

Consortium approach as it brings together different representatives from different background try to jointly proffer solution to a common problem which engender cooperation and team spirit. The challenges facing the consortium in the area of poor storage facility, delay in input delivery, delay in loan disbursement, high interest rate, multiple taxes, trust issue, shortage of training staff and field resources, export ban, local way of drying paddy, lack of gender-friendly labour saving technology and working capital constrains should be looked into. Addressing the identified challenges would make the approach to yield more value addition. The approach should be extended to other farmers, crops and regions.

Due diligence is required in the selection of partners who are not only competent but committed to keeping to the contract and ensures that partnership is not a zero sum game but a win-win relationship that ensures smallholder farmers are well integrated. The dependency on donors for continuity, less youth involvement, and lack of gender-friendly labour saving technology should be reconsidered. 


\subsection{Recommendations}

The report recommends as follow;

\subsubsection{Farmers}

It was observed during the study that there are differences in terms of yield even among farmers who cultivate the same size of land, this may be as a result of different farm practices, or some started planting early while others were waiting for adequate supply of rainfall. Good Agricultural Practice should be employed by all farmers bringing to bear the training and extension services. The farmers need modern implement as many of them still use manual labour for what should be done mechanically.

Groups should leverage the potential paddy consortium to catalyze social programs (storage, educational \& health, etc.) from other institutions. Better schedule of water management to reduce conflicts arising thereto and better demarcation of plots between farmers to avoid conflict during harvesting with combined harvester. Foster cooperation among farmers and farmers group. To improve the level of default, farmers group should encourage and ensure members who receive loan payback. In facilitating loan repayment, groups should provide guarantee on the credit worthiness of members. Input suppliers should work with farmers to minimize water contamination with agrochemicals to reduce associated health challenges as well as adapt better ways of fumigating farms to reduce health implication on farmers. Farmers should weigh the cost-savings of transportation of inputs by comparing the effectiveness of either getting delivery direct from input suppliers or bearing the cost of transportation from input suppliers to farmers group. The option of bearing the cost of transportation would require farmers comparing the cost of hiring truck from the lead firm or other commercial transporters.

Farmers group should pull resources (paddy) together by expanding production to take advantage of financing encapsulate in warehouse receipt system (WRS).

\subsubsection{Inputs Suppliers}

Timely supply of inputs to farmers in line with farming calendar and timely delivery to farmers groups to avoid associated costs of untimely delivery on production outputs. Farmers should not be at the receiving end of delay in processing of input credit advance from bank by input suppliers. To boost timely delivery of inputs, input suppliers should provide input credits to farmers and get reimbursement from bank through the existing payment arrangement. Farmers should be given trade discount for bulk purchase of inputs from input suppliers. There should be increase education and follow up/through with farmers on better use and application of inputs. Training of farmers on better application of inputs as indicated by farmers and observed in the study. The training should ensure timeliness and frequency. Work with other actors including farmers to incorporate drought tolerant, early maturing and pest resistant improved seeds variety as a mitigating measure to climatic change conditions in line with climate smart agriculture.

\subsubsection{Financial Institutions: Bank}

Timely processing and disbursement of loan to farmers and release of payment for input credit advance to input supplier. Provide special bonus package to farmers to offset the burden of the interest charge. Work with Bank of Tanzania to provide one-digit interest rate to farmers in line with poverty reduction and growth enhancement of micro, small and medium enterprises (MSMEs) programs. Provide equipment loan facilities to farmers to procure genderfriendly labour saving technologies to mechanized and reduce workload of farmers especially women. Promotional advertisement contract should be awarded to best performing farmers as brand ambassadors. The financial institutions should put in place a monitoring mechanism to ensure that the loan obtained by AMCOSS in the name of farmers really get to the farmers.

\subsubsection{Lead Firm}

Expand the financial access net to attract more financial institutions (banks) to be partners in the consortium. Expand the net of the consortium to accommodate other farmers, region and other crops by replicating the approach. Set up a monitoring and evaluation framework integrated with gender specialist for the consortium in line with sustainability plan. Institute a revolving fund to provide for training needs, coordination and internal finance strengthening to provide for input credit needs of farmers so as to minimize delay of loan processing from bank. Adapt more technology in the area of modern equipment of drying of paddy as against using local way of drying paddy on tarpaulin. Work with key stakeholders in rice food subsector leveraging on networking to attract development program interventions and funding to strengthen the business and impact on rural poverty reduction and commercialization of smallholder farmers. Strengthen the firm's competiveness, improve on product standardization and promotion and ensure that price negotiation with farmers reflect market reality in addition facilitate improvement on joint planning of partners. Gradual exit of MIVARF with sequential programs involving full participation of other partners.

\subsubsection{Mivarf}

Most of the farmers still have problem with storage facilities in spite of their involvement in the consortium platform, even though technical supports, extension services, training was not much of a problem for the farmers before joining the platform. Wards and farmer groups that are deficient in terms of storage facility should be looked into. There seem to be more concentration on marketing than production, a balance should be maintained in this regard. The farmers are not able to meet the market demand because production is solely dependent on natural rainfall. There is therefore need for irrigation scheme. There is need for technology improvement to increase production in order to meet market demand. There is problem of drought due to climate change, diseases attack on crops. Problems such as lack of feeder roads, infrastructure, farm machinery still confront the farmers. MIVARF need to do something about all these. 


\subsection{Policy Implication: Creating Enabling Environment}

The government believe that the lake zone does not need more attention because they receive 2 model of rainfall in a year, so, it concentrate on those part of the country that receive just one model of rainfall in a year. Adequate attention should be given to all zones because each zone has its uniqueness in terms of the crop they cultivate.

Not many youth are involved in agriculture which raises questions about the future and sustainability of agriculture in Tanzania. Government and MIVARF need to relax their rules to encourage more youth participation. There is always fluctuation in terms of annual production depending on rainfall distribution per year. There is therefore need for irrigation scheme in this zone to allow farmers cultivate all year round without depending on natural rainfall alone.

Need to develop crop or rain insurance for small scale holder producers (DRT, 2012) [19] Government should benchmark policy impacts on rural areas especially on smallholders (rural lens concept). While politics of food will continue to be there, the outcome should not be at detriment of commercializing smallholders. Effort should be increased in tackling smuggling of rice into the country with institutional strengthening and citizens' enlightenment.

Develop and promote crop and rain insurance for smallholders to ameliorate the risk of climate change effect (DRT, 2012) [19]. GOT should work out an insurance package for smallholders and also develop PPP on agricultural insurance.

The GOT should work with the EAC Partner States to operationalize the EAC Climate Change Fund to leverage on the Green Climate Fund and other climate finance mechanism to mitigate climate change effects. Provision of weather forecast infrastructure to disseminate information through two-way communication to farmers to reduce loss associated with climatic change condition. Infrastructure should prioritize linking smallholders to market, in order to close the gap of low productivity and income (SID, 2016). [20]

It strongly recommended that more time and resources be made available to strengthen the relationship and key partners in the consortium of rice farmers in Sengerema so that the consortium have a strong footing and that in the process focusing more on key sustainability elements so that after that period the system continues without support of external partners (Service Provider).

The consortium developed with the support of MIVARF intervention are still depending on financial support from the MIVARF program at $100 \%$. Upon the close of the support from MIFARF, there will be no existence of the initiated innovation platforms, due to the fact that they all lack element of sustainability including institutional, financial, technical and importantly the main off-taker. Unlike the Rwanda case where the off-taker is the main player addressing both forward and backward sector production and growth potentials. The current existing platforms is run as the stakeholder platforms, while it as well consists of the buyer or the so called off-takers, but it is a fact that they were not adequately selected based on a thorough due diligence backed with merits of their investment in the subsector and future growth plan and potential.

It is therefore important for the MIVARF to look at how the lessons learnt can be demonstrated by the delegates who got this opportunity as an entry of scaling the lessons beyond the Lake zone from paddy even other sectors.

\section{References}

[1] CARD - IFAD (2010): Mapping of poverty Reduction Strategy Papers, Sector Strategies and Policies Related to Rice Development.

[2] Lundy, M., Gottret, M. V. and R. Best. 2012. Linking research and development actors through learning alliances in agricultural innovation systems: An investment sourcebook. Washington, DC: World Bank. 344-348.

[3] Mwatawala. M. Et al. (2016) The potential distribution of Bactrocera dorsalis: Consedering phenology and irrigation patterns. Publication of Climate Change Agriculture and Food Security (CGIAR) 2016-02.

[4] Damian M. G (2013) Barriers to trade for smallholder farmers in Tanzania, a review and analysis of agricultural related market policies in Tanzania, Sokoine University of Agriculture.

[5] IFAD (2010) IFAD's Capacity to Promote Innovation and Scaling Up. Corporate-level Evaluation. Report No. 2240.

[6] Report on MIVARF support program Rwanda's cereals and pulses consortium visit (Sengerema, Magu, Chato and Msalala Platforms) prepared by: James Wembe (SP- Sengerema) \& Fredrick Ogenga (SP - Msalala and Chato) August 2017.

[7] ESA-BMO Network (2009). Policy Advocacy Strategy: Improving SME Market Access through Public and Private Procurement.

[8] Andrew W. Shepherd. (2007) "Approaches to linking producers to markets," RIAD Paper 13, FAO, Rome, 2007, A review of experiences to date.

[9] Klerkx, L., van Mierlo, B. and Leeuwis, C. (2012). Evolution of systems approaches to agricultural innovation: Concepts, analysis and interventions. In: Darnhofer, I., Gibbon, D. and Dedieu, B. (eds).

[10] Makini, F. W., Kamau, G. M., Makelo, M. N. and Mburathi, G. K. (2013). A guide for managing and developing innovation platforms. Nairobi, Kenya: Kenya Agricultural Research Institute / ACIAR.

[11] Nederlof, E. S. and Pyburn, R. (2012). One finger cannot lift a rock: Facilitating innovation platforms to trigger institutional change in West Africa. Amsterdam: Royal Tropical Institute.

[12] The Technical Centre for Agricultural and Rural Cooperation (CTA) (2002). Marketing Strategies for Small-Scale Farmers. Rural Radio Resource Pack: Sharing knowledge, improving rural livelihood.

[13] East African Business Council (EABC) (2005). A Study on NonTariff Barriers (NTBs) \& Development of a Business Climate Index in the East Africa Region. GTZ Project of "Support of Regional Business Organizations in East Africa (SRBO-EA). 
[14] Van Schalkwyk et al (2012) Unlocking Market to Smallholders, Lesson from South Africa. Mansholt Publication Series.

[15] Tanzania Census General Report 2012, pg 173.

[16] Lundy, M., Gottret, M. V. and R. Best. 2012. Linking research and development actors through learning alliances in agricultural innovation systems: An investment sourcebook. Washington, DC: World Bank. 344-348.

[17] FAIDA, (2000). Linking Farmers to Markets: Applying the Market Linkage Approach at Farmer, Company and Facilitator Level (in prep).
[18] Karfakis \& Rapsomanikis (2018) The Economic Lives of Smallholder Farmers.

[19] DRT (2012) Agriculture and small scale producers in Uganda: Issues, Challenges and Options for policy, Policy Brief Available at: http://drt-ug.org.

[20] SID (2016) The State of East African Report. Consolidating Misery? The Political Economy of Inequality in East Africa. A Publication for Society for International Development available at: https://www.sidint.net/content/state-east-africareport-2016-consolidating-misery-political-economyinequality. 